\title{
Hidden Curriculum and its Relationship with the Student Character Building
}

\author{
Imam Gunawan \\ Department of Educational Administration \\ State University of Malang, Indonesia \\ imam.gunawan.fip@um.ac.id \\ Desi Eri Kusumaningrum \\ Department of Educational Administration \\ State University of Malang, Indonesia \\ desi.eri.fip@um.ac.id
}

\author{
Teguh Triwiyanto \\ Department of Educational Administration \\ State University of Malang, Indonesia \\ teguh.triwiyanto.fip@um.ac.id \\ Wildan Zulkarnain \\ Department of Educational Administration \\ State University of Malang, Indonesia \\ anzwild@gmail.com
}

\author{
Ahmad Nurabadi \\ Department of Educational Administration \\ State University of Malang, Indonesia \\ ahmad.nurabadi.fip@um.ac.id
}

\begin{abstract}
The purpose of this research is to know the effect of the hidden curriculum on the student character building. This study uses a quantitative approach. The instrument used to measure the indicator of research variables is a rating scale questionnaire. Sampling technique using quota random sampling. The sample research is 38 students. Analysis of research data used is regression analysis. The result of data analysis concludes that there is significant effect of hidden curriculum variable $(\mathrm{X})$ on the student character building $(\mathrm{Y})$. The coefficient of regression of the hidden curriculum variable $(\mathrm{X})$ on the student character building $(\mathrm{Y})$ is .511 . The effective contribution of hidden curriculum variable $(\mathrm{X})$ to the student character building $(\mathrm{Y})$ is $26.2 \%$. While the remaining $73.8 \%$ comes from other variables.
\end{abstract}

Keywords: hidden curriculum, student character building

\section{INTRODUCTION}

Student organization is a forum for students to develop competencies other than academic competence that he got in lecturing activities. Many elements of the hidden curriculum can be developed in the activities of student organizations. Students who are active in the activities of student organizations will have more experience when compared to just attending college. The hidden curriculum is as everything that happens when the execution of the ideal curriculum becomes factual. The form of the hidden curriculum is a trust, value, and norm that will affect learners in their life.

The hidden curriculum should refer to the unspoken or implicit values, behaviors, procedures and norms that exist within the educational setting (Alsubaie, 2015). A hidden curriculum will occur whenever there is an effective relationship with the academic community, which includes the interaction of lecturers, students, class structure, and overall student organization patterns as a social value system. The hidden curriculum means that hidden things are not explicitly written in formal guidelines, but are not always hidden from the public view (Takahiro, et al., 2014; Gunawan, 2017). The hidden curriculum becomes an important factor in the process of character building of learners.

The lecturers' habits, the behaviors that lecturers show, the campus climate, and even the students themselves are part of a hidden curriculum that can influence and shape the learner's character. The character building becomes an important thing to continue to be carried out continuously and continuously, so that a nation has a good generation that has good character. Character building for students as future leaders is very important to be instilled. Character is a manifestation of behavior that is done consistently and not stands alone, meaning that the character is integrated with the attitudes and values that are believed by someone (Fahmy, et al., 2015; Gunawan, 2012).

The character building must be done in harmony with the nation's way of life and the attitude of community life which is the result of reflection of the diversity of society (Ferdiawan, et al., 2013; Gunawan, 2015). A student has a moral responsibility to develop the moral values of the nation manifested in his behavior with the guidance on the ethics and character of the nation. The hidden curriculum developed in student organizations is a strategic step in shaping the character of the students. A well-managed student organization will have an impact on the optimal implementation of a hidden curriculum that can shape the student's character into a tough person. The purpose of this study is to determine the effect of the hidden curriculum on the student character buildings.

\section{METHODS}

This study uses a quantitative approach. The research variables are: hidden curriculum (X) as predictor variable and student character building (Y) as the criterion variable. Hidden curriculum variable indicators (X) are leadership, confidence, creativity, priority management, time management, negotiation skills, tolerance, conflict management, decision making, and communication skills. Indicator of student 
character building variable (Y) is supporting words; quality time; gift; service; and physical touch.

The instrument used to measure the indicator of the variable is a rating scale questionnaire, ie respondents are asked to answer the statement by putting a cross $(\mathrm{X})$ on one of the appropriate columns between the four columns of answer that show four levels of attitude scale. The sample of this research is student activist of KSR PMI Unit Universitas Negeri Malang. Sampling technique using quota random sampling. The sample size is 38 students. Analysis of research data used is regression analysis (Gunawan, 2016; Gunawan, 2013; Gunawan, 2016a). Data analysis using IBM SPSS Statistics 20.

\section{RESULTS}

The hypothesis of the research being tested is that there is a significant influence of the hidden curriculum $(\mathrm{X})$ on the student character building $(\mathrm{Y})$.
Hypotheses were tested using regression analysis. The formula used to calculate how much the influence of the hidden curricula $(\mathrm{X})$ on the student character building $(\mathrm{Y})$ is the $\mathrm{t}$ test formula, using the 0.05 significance level $\mathrm{H}_{0}$ is rejected if the significance value obtained by $\leq 0.05$ and $\mathrm{H}_{0}$ is not rejected if the value of significance obtained for $>0.05$. The result of regression analysis of hidden curriculum variable $(\mathrm{X})$ on the student character building (Y) as in Table 1 .

Based on Table 1, the significance value of $0.000<0.05$ so $\mathrm{H}_{0}$ is rejected, it can be concluded that there is significant influence of hidden curriculum variable $(\mathrm{X})$ on the student character building $(\mathrm{Y})$. The coefficient of regression of hidden curriculum variable (X) on the student character building (Y) is 0.511 . The effective contribution of hidden curriculum variable (X) to the student character building (Y) is $26.2 \%$ (from $\mathrm{R}_{\text {Square }} \mathrm{X} 100=.262 \times 100=26.2 \%$ ). While the remaining $73.8 \%$ comes from other variables.

Table 1

Regression Analysis of Hidden Curriculum Variables on Student Character Building

\begin{tabular}{cccccccc}
\multicolumn{7}{c}{ Regression Analysis of Hidden Curriculum Variables on Student Character Building } \\
\hline R & R Square & Sum of Squares & df & Mean Squares & t & sig. \\
\hline .511 & .262 & 549.467 & 1 & 43.076 & 4.349 & 0,000 \\
\hline
\end{tabular}

Furthermore, based on the regression analysis, the regression equation of the coefficients(a) table as shown in Table 2. Based on Table 2 can be seen that the constant value $\left(\beta_{0}\right)$ is 41.471 ; and the value of the hidden curriculum variable coefficient $\left(\beta_{1}\right)$ of .370 . So the regression equation is: $\hat{Y}=41.471+.370 \mathrm{X}$. The constant of 41.471 states that if there is no increase in the score of the hidden curriculum variable $(\mathrm{X})$, then the score of student character building character (Y) is 41.471. The regression coefficient of .370 hidden curriculum variables $(\mathrm{X})$ states that any addition of one hidden grade curriculum variable score $(\mathrm{X})$ will give an increase of .370 .

Table 2

Coefficients $(a)$

\begin{tabular}{|c|c|c|c|c|c|c|}
\hline \multicolumn{7}{|c|}{ Coefficients $(a)$} \\
\hline & \multirow[t]{2}{*}{ Model } & \multicolumn{2}{|c|}{ Unstandardized Coefficients } & \multirow{2}{*}{$\begin{array}{c}\begin{array}{c}\text { Standardized } \\
\text { Coefficients }\end{array} \\
\text { Beta } \\
\end{array}$} & \multirow[t]{2}{*}{$\mathbf{t}$} & \multirow[t]{2}{*}{ Sig. } \\
\hline & & B & Std. Error & & & \\
\hline 1 & (Constant) & 41.471 & 9.536 & & 4.349 & .000 \\
\hline
\end{tabular}

a. Dependent Variable: Y_CharacterBuilding

\section{DISCUSSION}

The results of this study conclude that there is a significant effect of hidden curriculum variables on the student character buildings. The findings of this study support the research conducted by Woodhouse and Enukoha (1986) which concluded that the cultivation of morals and character to young people is very effective with the hidden curriculum within the school organization. The hidden curriculum can improve the effectiveness of successful student character building programs (Sulisworo and Aulia, 2017; Çubukçu, 2012). Students should be instilled moral values and good character. The character building of students must be programmed in teaching, formal curriculum, and hidden curriculum and integrated with school culture (Veugelers, 2010).

Learning by having the values of life and good character is an important part of the learning process in college. Educating students to have strong character requires lecturers who have an understanding of the values of education, behave based on morals, and have strong philosophical and pedagogical views based on tradition, local wisdom, and national culture. Character building is an effort to cultivate good behavior to students (Gunawan, 2011). These efforts must be supported by various parties so that the student character buildings can be achieved optimally. Creating a great nation, dignified, and respected by the world needed good society starting from the character building (Ainiyah, 2013). Character is a determinant of organizational climate, organizational work, and organizational competitive power.

There are five factors that must be considered by educational institutions so that the existing hidden curriculum can significantly influence the student character buildings, namely: (1) interpreting teachers' directions; (2) knowing teacher / adult-pleasing behaviors; (3) fitting in with other students; (4) working effectively in groups; (5) avoiding bullies (Myles, et al., 2013). If lecturers and universities want to optimize the hidden curriculum in order to form a good student character, it is necessary to understand 
how students learn, what students want, and how students behave (Moyse and Porter, 2015; Kusumaningrum, et al., 2018; Kusumaningrum et al., 2016). The characters that should be shaped within the students in the hidden curriculum are: punctuality; honesty; courtesy; responsibility; and respect to the others (Milson, 2000).

\section{CONCLUSION}

The result of data analysis concludes that there is significant effect of hidden curriculum variable on the student character building. The effective contribution of hidden curriculum variables to the student character buildings by $26.2 \%$. If it refers to the conclusions of the research, the university has the task to form the character of the students in accordance with the national values.

\section{ACKNOWLEDGMENTS}

Acknowledgments are conveyed to the Dean of the Faculty of Education, State University of Malang who has funded this research in the Non-Tax State Revenue Scheme of the Faculty of Education, State University of Malang.

\section{REFERENCES}

[1] Ainiyah, N. 2013. Pembentukan Karakter melalui Pendidikan Agama Islam. Jurnal Al-Ulum, 13(1), 2538.

[2] Alsubaie, M. A. 2015. Hidden Curriculum as One of Current Issue of Curriculum. Journal of Education and Practice, 6(33), 125-128.

[3] Çubukçu, Z. 2012. The Effect of Hidden Curriculum on Character Education Process of Primary School Students. Educational Sciences: Theory \& Practice, 12(2), 1526-1534.

[4] Fahmy, R., Bachtiar, N., Rahim, R., and Malik, M. 2015. Measuring Student Perceptions to Personal Characters Building in Education: An Indonesian Case in Implementing New Curriculum in High School. Procedia - Social and Behavioral Sciences, 211, 851858.

[5] Ferdiawan, E., and Putra, W. A. 2013. ESQ Education for Children Character Building based on Phylosophy of Javaness in Indonesia. Procedia - Social and Behavioral Sciences, 106, 1096-1102.

[6] Gunawan, I. 2011. Organizational Citizenship Behavior. Education Policy Analysis Archives, 2(3), 11-17.

[7] Gunawan, I. 2012. Mengembangkan Karakter Bangsa Berdasarkan Kearifan Lokal. Prosiding Seminar Nasional Meretas Sekolah Humanis untuk Mendesain Siswa Sekolah Dasar yang Cerdas dan Berkarakter, PGSD FKIP Universitas Muhammadiyah Surakarta, Surakarta, p. 67-79.

[8] Gunawan, I. 2013. Statistika untuk Kependidikan Sekolah Dasar. Yogyakarta: Penerbit Ombak.

[9] Gunawan, I. 2015. Values and Ethics in Educational Leadership: An Idea of Character Building of Students. Conference Proceedings Character Education in Indonesia Concepts and Applications in Primary Schools, PGSD IKIP PGRI MADIUN, Madiun, p. 113.

[10] Gunawan, I. 2016a. Metode Penelitian Kuantitatif. Retrieved June 7, 2017, from http://fip.um.ac.id/wpcontent/uploads/2015/12/2_Metpen-Kuantitatif.pdf.
[11] Gunawan, I. 2016b. Pengantar Statistika Inferensial. Jakarta: Rajawali Pers.

[12] Gunawan, I. 2017. Instructional Management in Indonesia: A Case Study. Journal of Arts, Science \& Commerce, 8(1), 99-107.

[13] Kusumaningrum, D. E., Sumarsono, R. B., and Gunawan, I. 2016. Principal Empowerment Through Soft System Methodology Approach. Proceeding International Conferences on Education and Training, 2nd ICET Theme: Improving the Quality of Education and Training Through Strengthening Networking, Faculty of Education State University of Malang, p. 205-211.

[14] Kusumaningrum, D. E., Sumarsono, R. B., and Gunawan, I. 2018. Teachers Empowerment of Pesantren-Based Junior High School East Java Province Indonesia. Journal of Social Sciences and Humanity Studies, 4(3), 29-33.

[15] Milson, A. J. 2000. Creating a Curriculum for Character Development: A Case Study. The Clearing House, 74(2), 89-93.

[16] Moyse, R., and Porter, J. 2015. The Experience of the Hidden Curriculum for Autistic Girls at Mainstream Primary Schools. European Journal of Special Needs Education, 30(2), 187-201.

[17] Myles, B. S., Trautman, M. L., and Schelvan, R. L. 203. The Hidden Curriculum for Understanding Unstated Rules in Social Situations for Adolescents and Young Adults. New York: AAPC Publishing.

[18] Sulisworo, D., and Aulia. 2017. Modeling the Nationalism Character Building through Hidden Curriculum Attachment for High School Student at Frontier Area of Indonesia. Proceedings $4^{\text {th }}$ International Conference the Community Development in ASEAN.

[19] Takahiro, I., Kohei, K., and Fumio, O. 2014. The Hidden Curriculum and Social Preferences. Tokyo: The Research Institute of Economy, Trade and Industry (RIETI).

[20] Veugelers, W. 2010. Moral Values in Teacher Education. International Encyclopedia of Education, 3, 650-655.

[21] Woodhouse, H., and Enukoha, I. 1986. The Hidden Curriculum and Beyond: A Nigerian Case Study. International Journal of Educational Development, 6(2), 103-116. 